\title{
IMPLEMENTATING THE LECTURER'S INSPIRATIVE VALUES IN FACULTY OF EDUCATION SEMARANG STATE UNIVERSITY
}

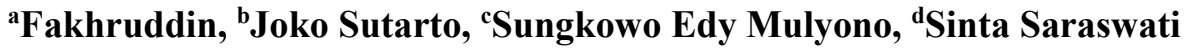

\author{
Faculty of Education \\ Universitas Negeri Semarang
}

Corresponding e-mail: afakhruddin@mail.unnes.ac.id, b jokotarto@mail.unnes.ac.id, ${ }^{c}$ sungkowo.edy@mail.unnes.ac.id, ${ }^{\mathrm{d}} \operatorname{sinta} @$ mail.unnes.ac.id

\begin{abstract}
Inspiration values modeled by lecturers in their work and function have strategic role especially for student learning both inside and outside. The problem is, how much inspiration values the lecturer showed in learning activities, including in doing research and community service. Data was collected using questioner, with proportional subject qualification on lecturers in Faculty of Education The research showed that lecturers implementing inspiration values in classes and community services can be categorized as adequate, while research activities fell into adequate enough category. Similarly, when deducted from mean research activity score, especially on published journal articles in reputable international journals, a score was lowest, yet the score was high in social aspects. Based on the finding result it is suggested to organize intensive periodic training, accompaniment, and monitoring to all lecturers.
\end{abstract}

Keywords: Inspiration Value; Lecturer.

\section{INTRODUCTION}

As an educator, the profession of lecturer is a noble figure as it bears a huge responsibility in developing the intellectual, emotional, and spiritual capacity of the students. In consequence, the mere knowledge upon the lectures is insufficient as lecturer should also be attentive towards the students' situation in order to be the inspiring role model for the students for the sake of students' character building. This ability becomes even more essential in Teaching Training Institutions. The lecturer shall master the strategy to educate, to inspire, to understand the students' psychological state, and to motivate the projected-teachers.

Through the abovementioned quality, lecturer can be the inspiration, fellow friends, and other significant roles altogether. Even though it is hard to become one, yet it is not impossible. Inspiring lecturers are those who are able to provide educational service for students with various backgrounds, either in terms of physical, intellectual, or socio-emotional aspect. Within the leg indicator, inspiring lecturers are expected to be someone who can motivate and inspire students while optimizing their potentials, especially in building the students' character as teacher-to be. This is because education is considered as the most effective tools in configuring the identity and character of individuals. As it is explained by Zubaedi [1] that character is constructed by three interrelated components, those are moral knowing, moral feeling, and moral behavior. Zubaedi also added that a good character indicated from the capacity of knowing the good, desiring the good, and doing the good.

Basically, character building is initiated by goodness. It is indicated by the existence of thinking. From the ability of thinking, the stimuli of doing good deeds occur. Raharjo [2] defined character education as the attempt of school personnel along with the parents and society to nurture children and teenagers to be care, virtuous, and responsible. In other words, character education is any attempts of educator/teacher/lecturer that intend to influence the character of students. These attempts include posing examples through the lecturer's attitude, the way of speaking, motivating the students, lecturing, and inspiring the students throughout the college activities for the sake of their future. Those are the importance of lecturer within the character education of their students.

Even so, according to the concept of Tri Dharma of Higher education, the roles above are just some part of lecturers' responsibility since they are still being obliged to conduct researches and social services for society in common. This is in line with the guidance book in developing the inspiring values by academic society in the Faculty of Education of Universitas Negeri Semarang. According to Aristotle, there are three main aspects that should be 
dynamically involved as the art of teaching in order to build the students' characters, those are ethos, patos, and logos. All three should be possessed by educators in hope that confidence, motivations, and inspiration will be nurtured within the students (Covey, 2005). In short, it is important that start from the board of directors (in the scope of university, faculty, major/study program), lecturers, and the educational staffs to implement the inspiring values, especially lecturer who constantly interacted with the students inside and outside the class. Lecturers are the main agent as they are involved in the learning process and even being fully responsible towards the development of their students' character. Therefore, lecturers are the first and the prominent stake holder in building the inspiring value for the students for the sake of their future.

Even so, according to the concept of Tri Dharma of Higher education, the roles above are just some part of lecturers' responsibility since they are still being obliged to conduct researches and social services for society in common. This is in line with the guidance book in developing the inspiring values by academic society in the Faculty of Education of Universitas Negeri Semarang. According to Aristotle, there are three main aspects that should be dynamically involved as the art of teaching in order to build the students' characters, those are ethos, patos, and logos. All three should be possessed by educators in hope that confidence, motivations, and inspiration will be nurtured within the students (Covey, 2005). In short, it is important that start from the board of directors (in the scope of university, faculty, major/study program), lecturers, and the educational staffs to implement the inspiring values, especially lecturer who constantly interacted with the students inside and outside the class. Lecturers are the main agent as they are involved in the learning process and even being fully responsible towards the development of their students' character. Therefore, lecturers are the first and the prominent stake holder in building the inspiring value for the students for the sake of their future.

The implementation of inspiring values done by lecturers in developing their inspiring character can be executed through four which each of them will be further discuss in this research. Those activities are lectures, researches, social services, and relationship building with fellow lecturers/ leaders/working partners. Because of all the reasons explained above, the researcher found the urgencies to conduct a study focusing on lecturers.

The objects of this research are the lecturers of Educational Sciences Faculty at Universitas Negeri Semarang. There were 82 lecturers as the sample and processes through the procedure of Multi Stage
Random Sampling. The data were acquired through questionnaire and being analyzed descriptively with the scale of 4 (four) category, those are satisfactory, sufficient, poor, and very poor.

\section{RESULTS AND DISCUSSION}

The four activities (lectures, researches, social services, and relationship building) done by lecturers in implementing inspiring values are being described by 45 questions, the results then categorized into 4 (four) scale. The lowest score obtained was 45 and the highest was 180 as shown in table 1.

Table 1. Scale of Inspiring Value Scoring Category

\begin{tabular}{cc}
\hline Score & Category \\
Interval & \\
\hline $147-180$ & Satisfactory \\
$113-146$ & Sufficient \\
$79-112$ & Poor \\
$45-78$ & Very Poor \\
\hline
\end{tabular}

Based on the category above, the average score obtained was 155.34 , the median was 158 , and the modus was 165 . When inserted in a graphic, a negative curve was formed. It means that those who gained above average score was much more than the below average. In other words, this class had good value of variability, or the above average score had higher frequency.

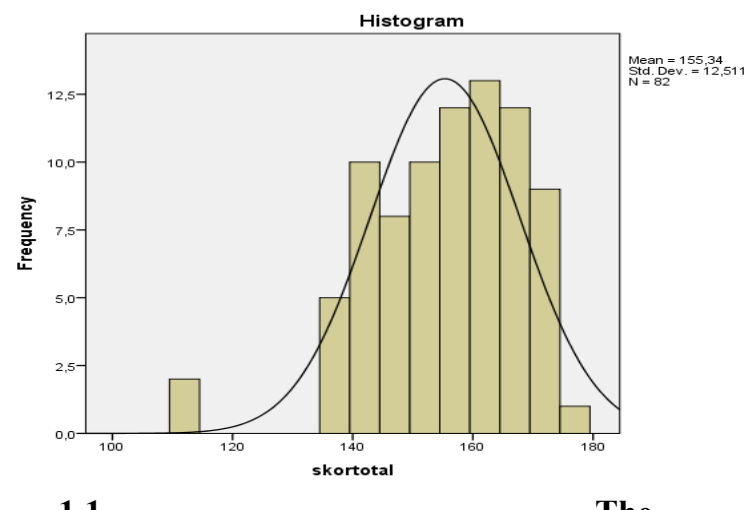

1.1

Implementations in Lectures

One of the main responsibilities of lecturers during lectures is transforming knowledge to the students in accordance with their major. Besides, lecturers also have to master other competencies in building the character of students as the future generations, one of the ways is by being the role model during the teaching and learning process. Students' character building may begin from the implementation of inspiring values by their lecturers. Lecturers as the role model or example for the students possess higher opportunities in building and developing students' character according to the dynamic demand of society. 
Below is the data of inspiring score of lecturers of Educational Sciencies Faculty at Universitas Negeri Semarang that is being implemented during lectures.

Table 2. Scale of Inspiring Value Scoring Category in Lectures

\begin{tabular}{cc}
\hline Interval & Category \\
Nilai & Satisfactory \\
\hline $43-52$ & Sufficient \\
$33-42$ & Poor \\
$23-32$ & Very Poor \\
$13-22$ & \\
\hline
\end{tabular}

The table above shows that the average score was 48.2 , the median was 50 , and the modus was 52. It can be seen that the implementation of inspiring values during lectures done by the lecturers of Educational Sciences Faculty at Universitas Negeri Semarang is considered satisfactory. When inserted in a graphic, a negative curve was formed. It means that those who gained above average score was much more than the below average. In other words, this class had good value of variability, or the above average score had higher frequency.

\subsection{Implementation in Researches}

Tri Dharma of Higher Education does not only expose lecturers with the duty to conduct lectures but also researches. This aims to always develop the knowledge of the lecturers accordingly to their major. Not only that, in order to promote themselves to higher position they also have to be active in doing researches.

The implementation of inspiring values done by lecturers in Educational Sciences Faculty in researches is shown in table 3 .

Table 3. Scale of Inspiring Value Scoring Category in Researches

\begin{tabular}{cc}
\hline Scoring & Category \\
Interval & Satisfactory \\
\hline $30-36$ & Sufficient \\
$23-29$ & Poor \\
$16-22$ & Very Poor \\
$9-15$ &
\end{tabular}

2.2 Based on the table above, it can be calculated that the average score was 23.3, the median was 23.5 , and the modus was 27 . It can be seen that the implementation of inspiring values during lectures done by the lecturers of Educational Sciences Faculty at Universitas Negeri Semarang is considered sufficient. When inserted in a graphic, a negative curve was formed. It means that those who gained above average score was much more than the below average. In other words, this class had good value of variability, or the above average score had higher frequency.

\subsection{Social Services}

The inspiring values implemented by lecturers during the social services commonly done in terms of practicing the knowledge, technology, cultural arts, etc to the society in common through scientific method as one of the goals of Tri Dharma for Higher Education as well as the noble duty in developing the society in order to accelerate the growth of society to fulfill the demand of national development. Technically, the project of social services is managed by Research and Social Service Institution (LP2M) and the Faculty through the procedure of selection. Even so, lecturers may conduct individual and incidental social services adjusted to the need of societies or related institutions.

Related to the objective of social service, the activity can be in the form of education, social work, student study service, integrated rural development and research findings development. Based on the data obtained from the lecturers' questionnaire, the implementations of inspiring values during social services activity is presented in table 4.Table 4. Skala Kategori Nilai Inspiratif Bidang Pengabdian pada Masyarakat

Table 4. Scale of Inspiring Value Scoring Category in Social Service

\begin{tabular}{ll}
\hline $\begin{array}{l}\text { Scoring } \\
\text { Interval }\end{array}$ & Category \\
\hline $23-27$ & Satisfactory \\
$18-22$ & Sufficient \\
$13-17$ & Poor \\
$8-12$ & Very Poor \\
\hline
\end{tabular}

The table above presented that the average score was 23.12 , the median was 24 , and the modus was 25 . It can be seen that the implementation of inspiring values during social services done by the lecturers of Educational Sciences Faculty at Universitas Negeri Semarang is considered satisfactory. When inserted in a graphic, a negative curve was formed. It means that those who gained above average score was much more than the below average. In other words, this class had good value of variability, or the above average score had higher frequency. 


\subsection{The Implementation of Inspiring Value in Relationship Building}

As one of the components of academic society, lecturers are responsible to preserve the reputation of one university. Lectures are expected to build positive attitude, obey the professional ethic code during the teaching and learning process both within and outside the university as the sign of good personality and social competence mastery. Therefore, the implementation of inspiring values in terms of relationship building is essential, especially in building the relationship with leaders, fellow lecturers, working partners and students. Below is the analysis data of the implementation of inspiring values in relationship building.

Table 5. Scale of Inspiring Value Scoring Category in Relationship Building

\begin{tabular}{cc}
\hline Scoring & Category \\
Interval & \\
\hline $52-63$ & Satisfactory \\
$40-51$ & Sufficient \\
$28-39$ & Poor \\
$16-27$ & Very Poor \\
\hline
\end{tabular}

Based on the table above, it can be calculated that the average score was 62.7 , the median was 64 , and the modus was 64 . It can be seen that the implementation of inspiring values in building relationship done by lecturers of Educational Sciences Faculty at Universitas Negeri Semarang is considered satisfactory. When inserted in a graphic, a negative curve was formed. It means that those who gained above average score was much more than the below average. In other words, this class had good value of variability, or the above average score had higher frequency.

Hence, according to the research findings, the most prominent aspect among four activities in implementing the inspiring values is the aspect of relationship building. While the lowest score obtained from researches. If we sort the activities based on the highest score, the list would go on as relationship building, lectures, social services, and researches. The list is demonstrated in the pie chart below.

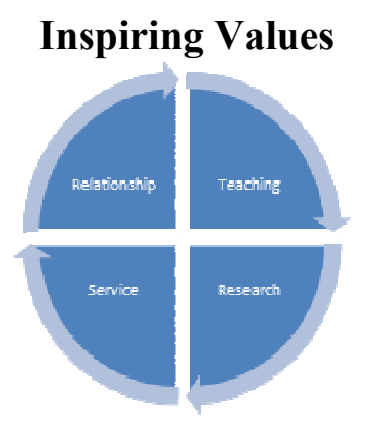

Figure 1. Inspiring Value

Based on Figure 1, the indicator of each aspect presented that (a) the most prominent implementation of inspiring value during lectures is being fair to all students without discriminating any of them and develop the students' academic capability objectively, (b) the hindering element in research is the obligation to publish articles in the reputable journals (c) The most significant implementation of inspiring values in social services in providing services to all groups without any discrimination, while the lowest implementation is inventing new useful technology for society, (d) The highest implementation of relationship building is communicating in polite manner to the leaders, yet the poorest implementation is thinking positively towards the leader.

All and all, the research findings contribute the conclusion that the process of character building is in line to what stated by Lickona (2012:82) who classified character into three character, those are moral knowing, moral feeling, and moral action. The implementation of inspiring values allows students to learn independently in developing and utilizing their knowledge, as well as practicing and internalizing the character in the daily life. Moreover, when this process is being programmed in an integrated and balanced management that focuses on the character building for the students in accordance with the standard competence for graduates in every institution unit (Mulyasa, 2012:9). Thus, the implementation of inspiring values by lecturers plays important role in students' character building.

The indicator of implementations that still below the standard is in terms of research which the lecturers are lack of doing researches and publish it in reputable international journals. In this particular case, Megawangi (2004:38) stated that character building does not only make someone to have good attitude, but also increase the percentage of academic success rate. Hence, the implementation of inspiring values during lectures, researches, social services, and relationship building will influence the students 
achievement in terms of their manner, intellectual, diligence, teamwork, and empathy toward social issues.

\section{CONCLUSION AND SUGGESTION}

In conclusion, the implementation of inspiring values by the lecturers of Educational Sciences faculty at Universitas Negeri Semarang during the lectures, social services, and relationship building are higher than the implementation in researches. The indicator of relationship building is the highest implementation with the score of 3.91 through the practice of polite communication with the leaders. In contrast to the number of published researches that only obtain the score of 1.41 .

Therefore, it is suggested to set the priority in academic management related to publishing articles in the international reputable journals. It needs more action by conducting further training and guidance, especially for the junior lecturers. Besides, there should also be an intensive monitoring and evaluation.

\section{REFERENCES}

[1] Adishakti. (2007). Pelestarian Bahan Pustaka http://www.scribd.com/doc/51637900/ pelestarian bahan pustaka accessed on 02 april 2014

[2] Lickona, Thomas, (2012). Educating for Character. Jakarta: Penerbit Bumi aksara.

[3] Mulyasa, HE, (2013). Manajemen Pendidikan Karaker. Jakarta: Penerbit Bumi aksara

[4] Megawangi, Ratna, (2004). Pendidikan Karakter: Solusi yang tepat untuk membangun bangsa. Jakarta: Yayasan IHP.

[5] Dasman, RF. (1968). Sebuah Aneka Negara. MacMillan Company, New York. ISBN 0-02072810-7.

[6] Harsono, Hanifah. (2002). Implementasi Kebijakan dan Politik. Yogyakarta: Rhinheka
Rasa. $\quad$ http://www.biologyonline.org/dictionary/Conservation, diakses pada 29 Maret 2009

[7] Irwanto.(2006). http://www.indonesiaforest.net/silvika.html

[8] Karim, Fatkurrahman Abdul. (2011). Konservasi Alam, Gerakan hijau, dalam Suatu Perspektif. http://unikonservasifauna.org/2011/10/konserva si-alam-gerakan-hijau-dalam-suatu-perspektif/ diakses tanggal 5 Mei 2014

[9] Nurdin, Usman. (2002). Konteks Implementasi Berbasis Kurikulum.

[10] Peraturan Rektor Unnes Nomor 27 Tahun 2012 tentang Tata Kelola Kampus Berbasis Konservasi di Universitas Negeri Semarang.

[11] Raharjo. (2010). Pendidikan Karakter sebagai upaya Menciptakan Akhlak Mulia. Jurnal Pendidikan dan Kebudayaan, 16. 3.

[12] Setiawan, Guntur. (2004). Implementasi Dalam Birokrasi Pembangunan.

[13] Sudrajat, A. (2010). Konsep Pendidikan Karakter. Dalam http://akhmadsudrajat.wordpress.com/2010/09/1 5/konsep-pendidikan-karakter/ diakses 21 Februari 2014.

[14] Sugiyono. (2008). Statistika untuk Penelitian. Bandung: Alfabeta.

[15] Tor-Björn Larsson. (2001). Biodiversity evaluation tools for European forests. WileyBlackwell, $\quad$ 178. ISBN 978-87-16-16434-6. Diakses 28 Juni 2011.

[16] Vale, Brenda \& Vale, Robert. (1991). Towards a Green Architecture: six practical case studies. RIBA Publications. ISBN 978-0-947877-47-7.

[17] Wahab, Solichin Abdul. (2004). Analisis Kebijakan Dari Formulasi ke Implementasi Kebijakan Negara. Jakarta: PT Bumi Aksara.

[18] Zubaedi. (2011). Desain Pendidikan Karakter: Konsep dan Aplikasinya dalam Lembaga Pendidikan. Jakarta: Kencana. 